\title{
SLAMF1 wt Allele
}

National Cancer Institute

\section{Source}

National Cancer Institute. SLAMF1 wt Allele. NCI Thesaurus. Code C104060.

Human SLAMF1 wild-type allele is located in the vicinity of 1q23.3 and is approximately 39 $\mathrm{kb}$ in length. This allele, which encodes signaling lymphocytic activation molecule protein, plays a role in initiating signal transduction networks in immune cells. 